\title{
Investigation of near-surface exchange processes in reactive paste tailings
}

\author{
V. Martin École Polytechnique de Montréal, Canada \\ M. Aubertin École Polytechnique de Montréal, Canada \\ M. Benzaazoua Université du Québec en Abitibi-Témiscamingue, Canada \\ G. Zhan Barrick Gold Corporation, United States of America
}

\begin{abstract}
The use of paste tailings is considered as a potentially advantageous alternative to conventional slurry tailings disposal, especially in areas where water resources are scarce. In order to assess the response of a paste tailings storage facility, one needs to analyse the near-surface moisture fluxes in the exposed tailings due to evaporation and drainage. In the case of sulphide bearing materials with an acid mine drainage (AMD) generating potential, it is important to evaluate the impact of desaturation that may lead to tailings weathering, i.e. oxidation. A key factor influencing production of AMD is the distribution of the pore water within the tailings.

This paper presents sample results from laboratory testing and numerical simulations that are being conducted to evaluate pore water movements in surface paste tailings. The study focuses primarily on columns tests made with paste tailings from Barrick Gold's Bulyanhulu Mine (Tanzania, Africa). These tests have been used to assess the evolution of paste tailings behaviour and their reactivity at the laboratory scale, with the help of numerical simulations. The oxidation rate is also investigated for different situations pertaining to the column tests results. The numerical simulations presented are a one-dimensional simplification of the tailings storage facility of Bulyanhulu Mine, and evaluate the impact of evaporation on the water balance of paste tailings deposited on surface. The main observations indicate that the oxidation of exposed reactive tailings is influenced by their degree of saturation and the evaporation plays an important role in the water balance of paste tailings exposed to near surface conditions.
\end{abstract}

\section{Introduction}

Proper management of mine tailings is important to the mining industry. In order to do so, different methods have been proposed by various actors in order to minimise the potential impact of mining operations on the environment (e.g. desulphuration of mine tailings, engineered covers, leachate treatment, etc.) (Aubertin et al., 2002; Bussière, 2007). One of the proposed solutions, surface disposal of paste tailings, is considered more frequently by mining operations to manage milling waste. The main difference with traditional mine tailings is that paste tailings have a lower gravimetric water content (w). This technique, for example, has an impact on the water management of a tailings storage facility compared to traditional tailings disposal, i.e. potentially less drainage water to handle and greater reuse of process water. Thus, the use of paste tailings for surface disposal influences the daily operation of a tailings storage facility. This paper presents some results from ongoing work aimed at evaluating the evolution of the properties and behaviour of paste tailings deposited on the surface, and to evaluate the differences with traditional tailings management.

It is useful, before introducing recent results, to recall the terminology used in this paper, which has been proposed by Martin et al. (2005, 2006a). It is based on commonly used definitions by other authors (e.g. Robinsky, 1999; Jewell et al., 2002; Li et al., 2002; Sofra and Boger, 2002; Benzaazoua et al., 2004; Crowder, 2004; Bussière, 2007; Deschamps, 2009). The tailings types are divided into four categories: slurried tailings, thickened tailings, paste tailings and filtered tailings (Table 1). The pulp density is used to define these categories. 
Table 1 Different types of tailings (adapted from Martin et al., 2006a)

\begin{tabular}{llll}
\hline Tailings Type & $\begin{array}{l}\text { Pulp Density (P), } \\
\text { (\% solids, w/w) }\end{array}$ & Yield Stress & Critical Velocity \\
\hline Slurried tailings & $<45$ & No & Yes \\
Thickened tailings & $45-70$ & Develops as P increases & Variable (smaller at higher P) \\
Paste tailings & $70-85$ & Yes & No \\
Filtered tailings & $>85$ & N/A (materials do not "flow") & N/A (materials do not "flow") \\
\hline
\end{tabular}

In Table 1, the pulp density (P) is expressed as percent solids, and it refers to the ratio of the mass of solids to the total mass of a tailings sample (it is assumed that the difference between the two masses is due to process water). The values of $\mathrm{P}$ given in this table typically apply to base and precious metal mines, for which the solid grains relative density $\mathrm{D}_{\mathrm{r}}$ (or specific gravity, $\mathrm{G}_{\mathrm{s}}$ ) is between 2.6 and 2.9. It is noted that the pulp volumetric density $\mathrm{P}_{\mathrm{v}}\left(=\mathrm{V}_{\mathrm{s}} / \mathrm{V}_{\mathrm{t}}=\right.$ volume of solid/ total volume) can alternatively be used to define the type of tailings (Martin et al., 2005), as it is considered more representative for $D_{r}$ values outside this range.

The yield stress corresponds to the stress necessary to initiate flow of the tailings. The critical velocity is the flow velocity below which the solid particles start to settle in the pulp. In low density tailings slurries, there will also be particle segregation during settling. The thickening and transport techniques refer to more practical aspects of tailings classification and serve to illustrate the differences in the preparation and handling of these materials.

It should also be specified here that once tailings are deposited in a tailings storage facility (TSF), they tend to consolidate, drain, and dry (regardless of the tailings type). Because of this, the differences in the properties (e.g. in-situ water content) of the tailings types may be attenuated over time (Blight, 2003). In the long term, one of the main differences observed between a TSF of slurried tailings and a TSF of paste tailings is that the former typically contains a series of segregated layers and zones of tailings having different properties (i.e. various particle size distribution, and porosity), while paste tailings will tend to be more homogeneous (Jewell et al., 2002). Paste tailings disposal may offer some advantages over traditional slurried tailings disposal, but it also has some limitations. It is therefore useful to investigate the conditions where this method may be applicable and preferable over more conventional tailings management techniques.

This project is conducted in collaboration with Barrick Gold, and refers to the properties of tailings from the Bulyanhulu mine site (Tanzania). This mine has been operating since March 2001 and has been depositing paste tailings in TSF from the onset. Laboratory tests results will first be presented, including basic properties of the tailings sampled at the mine. Then, the procedure developed to conduct column tests, designed to monitor the evolution of the hydrogeotechnical properties of the tailings, will be explained, followed by some key results and interpretation (linked to movement of pore water, and oxygen diffusion and consumption). Some numerical models, completed with the saturated/unsaturated flow software Vadose/W will be described in the paper. The models focus on the hydrogeological behaviour of the tailings under representative field conditions. The paper ends with a brief discussion and some closing remarks.

\section{$2 \quad$ Laboratory testing}

The tailings used to conduct the laboratory work have been sampled at the Bulyanhulu mine in Tanzania. The samples were collected downstream from the paste tailings mixer before pumping and deposition in the TSF, respectively, in October 2004 and July 2007, and are identified as Buly-04 and Buly-07. To minimise oxidation, the tailings were kept submerged and shipped to the laboratory in barrels or buckets. Once they arrived at the laboratory at École Polytechnique de Montréal (Canada), the tailings were flushed and mixed with fresh water (to remove process water), then homogenised and placed in 20 litre buckets under a water cover (to prevent oxidation). This material was used both for basic characterisation (Section 2.1) and also to develop some tests designed to gain an understanding of the properties of these tailings following deposition (Section 2.2). 


\subsection{Basic properties}

The properties that have been determined include the following: particle size distribution, specific gravity, saturated hydraulic conductivity, water retention curves, and oxygen diffusion and consumption parameters.

\subsubsection{Particle size distribution and specific gravity}

The particle size distribution (PSD) was obtained using the ASTM D 422 standard by dry-screening (sieving) and sedimentation. The results for Buly-04 and Buly-07 samples are shown on Figure 1. It can be seen that the two materials, although they have been sampled three years apart, have almost the same PSD. These tailings can be classified as a low plasticity silts (SM) using the united soil classification system (USCS; ASTM D 2487). These are relatively fine-grained when compared to other tailings (e.g. Vick, 1983, Aubertin et al., 1996, 2002; Bussière, 2007), with a $\mathrm{D}_{10}$ of 20 to $30 \mu \mathrm{m}$, a uniformity coefficient $\left(\mathrm{C}_{\mathrm{U}}\right)$ between 13 and 20 , and more than $70 \%$ passing the $80 \mu \mathrm{m}$ mesh. The specific gravity (ASTM D 854 ) of the Buly-04 tailings is 2.93 .

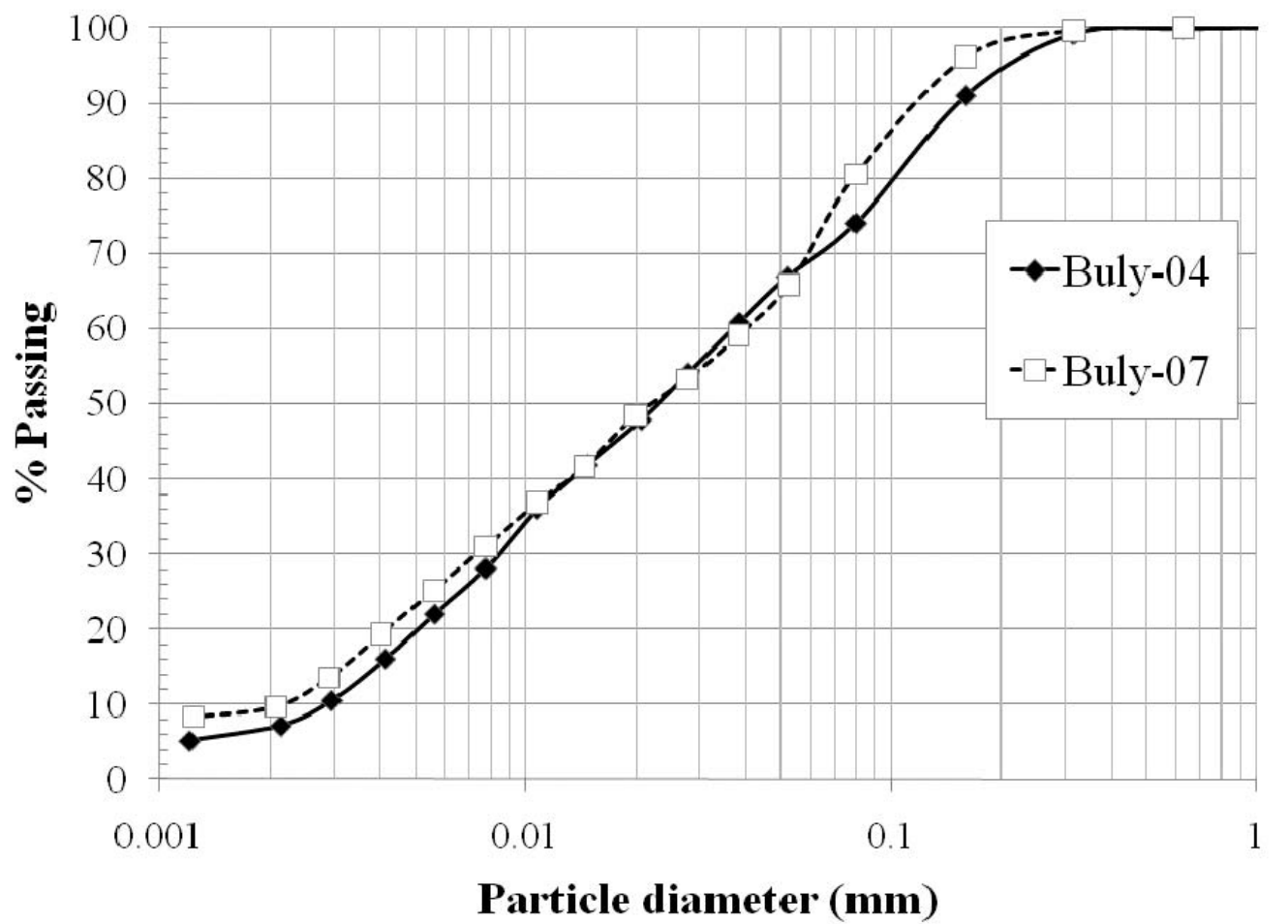

Figure 1 Particle size distribution curves for the Bulyanhulu tailings sampled in 2004 (Buly-04) and 2007 (Buly-07)

\subsubsection{Saturated hydraulic conductivity}

The saturated hydraulic conductivity $\left(\mathrm{k}_{\mathrm{sat}}\right)$ of the tailings was measured using variable head tests in a flexible membrane (triaxial cell) permeameter (ASTM D 5084). The results of the various tests are presented on Figure 2. In this figure, the measured hydraulic conductivity is also compared with the predicted hydraulic conductivity calculated using the Kozeny-Carman modified (KCM) model developed by Aubertin et al. (1996) and Mbonimpa et al. (2002); the KCM model uses basic geotechnical properties (i.e. grain size parameters, $\mathrm{D}_{10}$ and $\mathrm{C}_{\mathrm{U}}$, and void ratio, e) to estimate the saturated hydraulic conductivity of soils, tailings and other particulate media. The average measured hydraulic conductivity for the Buly-04 tailings is $1.3 \times 10^{-7} \mathrm{~m} / \mathrm{s}$ (for e of about 0.72 ) whereas it is $6.3 \times 10^{-8} \mathrm{~m} / \mathrm{s}$ for the Buly-07 tailings (for e of 0.65 ). These values of $\mathrm{k}_{\mathrm{sat}}$ are fairly low for mine tailings (Vick, 1983; Aubertin et al., 1996; Bussière, 2007). Figure 2 also shows that the predicted values obtained with the KCM model equation are higher but still close to the measured results (i.e. within the margin of error for these tests). 


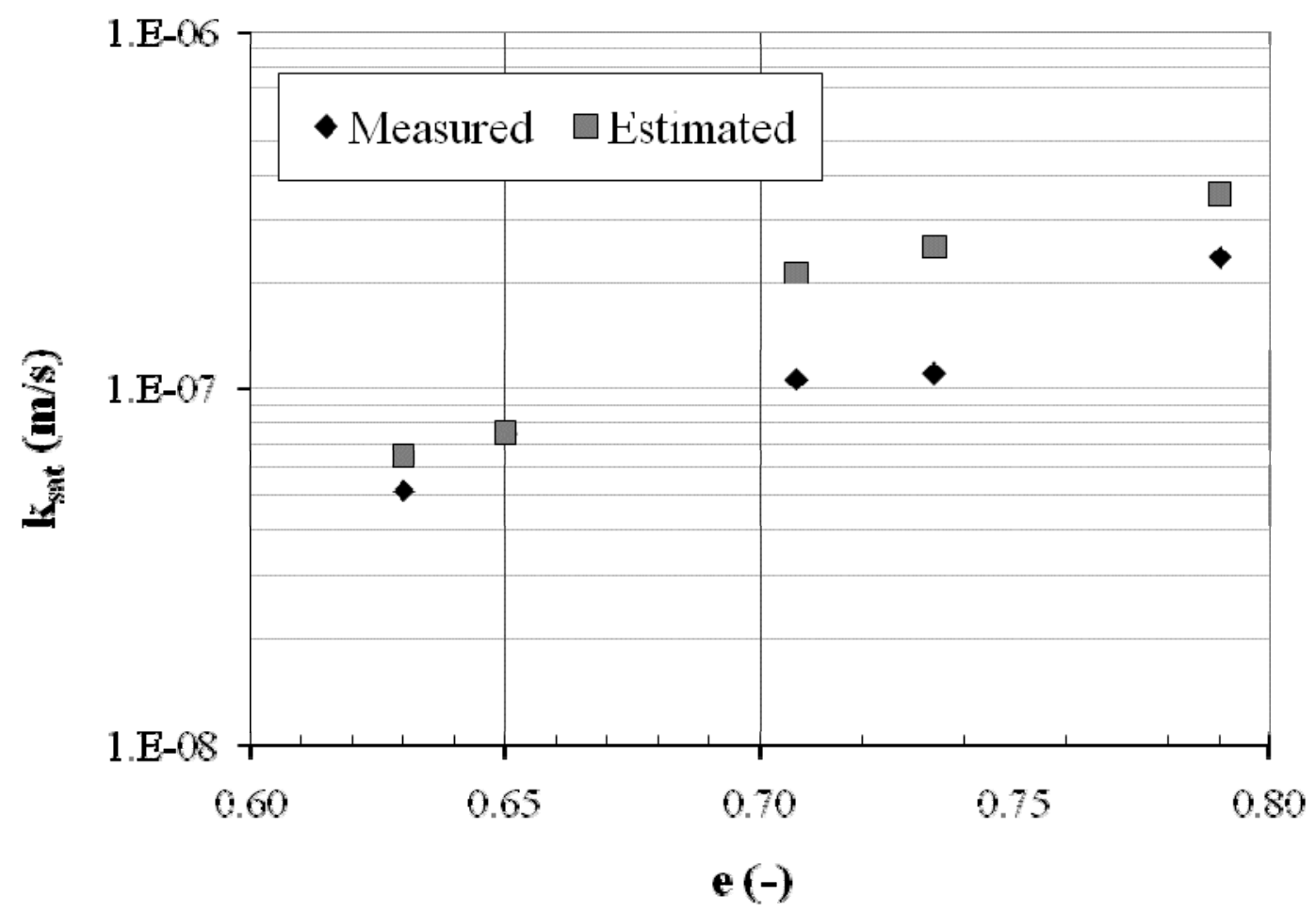

Figure 2 Saturated hydraulic conductivity $\left(k_{\text {sat }}\right)$ measured in the laboratory, as a function of the void ratio (e) for tests performed in flexible wall permeameters; estimated values obtained with the KCM model are also shown

\subsubsection{Water retention curves}

Because of their lower water content (compared with traditional tailings), paste tailings freshly deposited on the surface tend to desaturate more rapidly (within a few hours following deposition). This is particularly the case for the Bulyanhulu mine, located in Tanzania, where there are high daily temperatures, low humidity and little or no rainfall during 6 months of the year (SRK, 2002). The desaturation of fine-grained materials, such as tailings from hard rock mines, can be characterised using the water retention curve (WRC), which expresses the relationship between the volumetric water content $(\theta)$ and negative pore pressure (or suction, $\psi)$. The WRC of the Bulyanhulu tailings has been measured using two laboratory testing methods: the Tempe cell and the pressure plate extractor (described in Fredlund and Rahardjo, 1993). The WRC obtained with both apparatus for the Buly-04 samples are presented on Figure 3; the curves shown on the figure have been fitted to the van Genuchten (1980) equation. Because of space limitation, results for the Buly-07 are not presented, but these are fairly similar to those shown in Figure 3 (Martin, 2010).

It can be seen that the three tests give similar WRCs, once the air entry value (AEV; i.e. suction at which the tailings start to desaturate) is exceeded. This tends to confirm the homogeneity in the samples and also indicates good reproducibility of the results for these tailings (which has been confirmed by other tests, not shown here). It can be observed on Figure 3 that the AEV is between 25 and $70 \mathrm{kPa}$, depending on the initial porosity, whereas the suction at the residual water content $\left(\psi_{\mathrm{r}}\right)$ is around $1,000 \mathrm{kPa}$. The WRC of the paste tailings measured with the pressure plate extractor is somewhat different than the two others at low suction because the tailings in the pressure plate extractor were placed in a relatively looser state (i.e. at a higher water content, to mimic a paste like consistency). In Tempe cells, the materials are usually placed in a denser state (as was the case here), because volume changes cannot be directly monitored in the latter. However, it can be observed that all three curves practically converge at (or near) the AEV of the dense samples (about $70 \mathrm{kPa}$ ). Both testing methods applied here are reliable, but the pressure plate extractor is sometimes advantageous because it can be used to apply a larger suction (up to $10,000 \mathrm{kPa}$ ), and it also allows volume measurement of the tested specimens. More information on the volumetric variations of these paste tailings can be found in Saleh-Mbemba et al. (2010). 


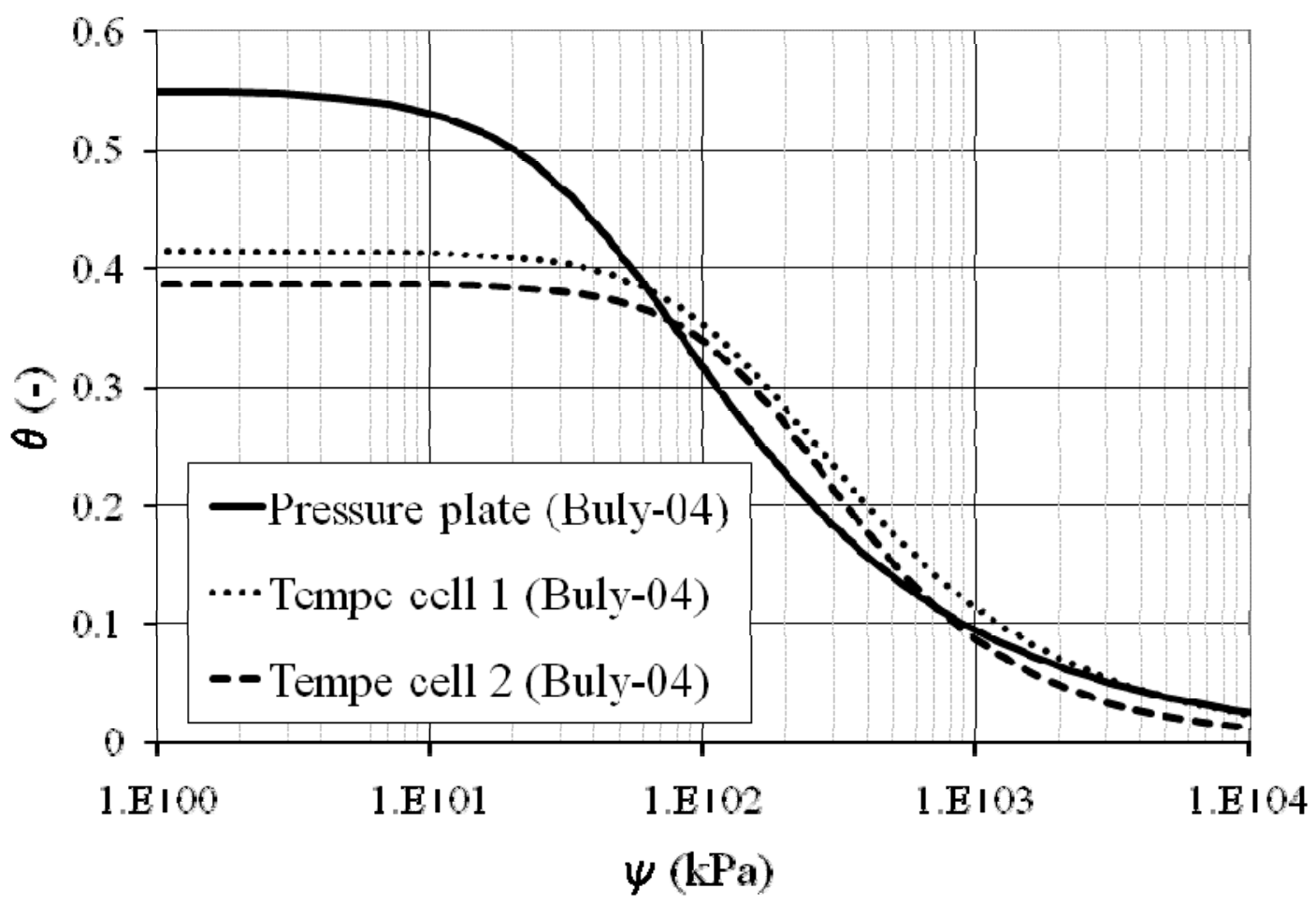

Figure 3 Water retention curves of the Bulyanhulu tailings measured with a Tempe cell and a pressure plate extractor (data fitted to the van Genuchten (1980) equation)

\subsubsection{Oxygen consumption and diffusion tests}

The last characterisation results that will be presented in this section have been obtained from the oxygen diffusion and consumption tests. These tests can either be conducted in the field or in the laboratory. The objective of these tests is to evaluate, for a given degree of saturation, the effective diffusion coefficient $\mathrm{D}_{\mathrm{e}}\left(\mathrm{L}^{2} / \mathrm{T}\right)$ and reaction rate coefficient $\mathrm{K}_{\mathrm{r}}\left(\mathrm{T}^{-1}\right)$ of tailings (or other materials). If the tailings react with oxygen $\left(\mathrm{K}_{\mathrm{r}}>0\right)$, this indicates that there may be potential for generation of acid mine drainage (AMD), depending on its neutralising potential. Such AMD occurs when the iron sulphide minerals contained in the tailings (e.g. pyrite, $\mathrm{FeS}_{2}$ ) are oxidised when in contact with water and oxygen. The oxidation reactions produce an acidic leachate that may also include high concentrations of sulphates and metallic ions (Kleinmann et al., 1981; Aubertin et al., 2002). For the oxidation reactions to occur in a significant manner (to produce acid), the tailings must be partially saturated (i.e. with $\mathrm{S}_{\mathrm{r}} \leq 85 \%$ approximately; e.g. Ouangrawa et al., 2006, 2009; Gosselin et al., 2007). As mentioned above, because paste tailings initially contain less water than typical slurried tailings, they can tend to desaturate more rapidly. Therefore, when the paste tailings are potentially acid generating, the time lag for oxidation to occur may be reduced.

The modified oxygen consumption (MOC) field tests are based on direct measurement of oxygen concentration in a closed reservoir, which can be linked to the oxygen flux into the tailings (Mbonimpa and Aubertin, 2003). The test is a variation on the testing procedure proposed by Elberling et al. (1994). The objective of the MOC test is to evaluate the value of parameters required to calculate the oxygen flux through uncovered (or covered) tailings, i.e. the effective diffusion coefficient $D_{e}$ and the reaction rate coefficient $\mathrm{K}_{\mathrm{r}}$. The test is designed to cause relatively minor disturbance of the materials. It consists of driving a stainless steel or aluminum cylinder (with a diameter of approximately $15 \mathrm{~cm}$ ) into the mine tailings to create a zone isolated from its surroundings (Bussière et al., 2002; Mbonimpa and Aubertin, 2003; Dagenais, 2005; Martin et al., 2006b; Gosselin et al., 2007). At the surface, a 2-5 cm headspace is left to create a closed oxygen chamber (see Figure 4(a)). The cylinder is then closed and sealed by a cap instrumented with an oxygen sensor to measure the decrease of oxygen concentration in the reservoir.

Somewhat similar tests can also be conducted in the laboratory, in large columns (Gosselin, 2007) and in small cells (Mbonimpa and Aubertin, 2003). In the latter case, the tailing sample (1-2 cm thick) is placed in 
a sealed cell (Figures 4(b) and 4(c)) with an approximate diameter of $10 \mathrm{~cm}$. The oxygen diffusion coefficient is obtained by monitoring the oxygen concentration in the two (source and receptor) reservoirs and calculating its flow through the material (Figure 4(c)). Initially, the upstream (source) reservoir has an oxygen concentration of roughly $21 \%$ (ambient concentration) whereas the downstream reservoir has a concentration of $0 \%$ (bottom of cell is flushed with nitrogen before the beginning of the test). Both parameters $\left(D_{e}\right.$ and $\left.K_{r}\right)$ can be obtained from these tests (Mbonimpa and Aubertin, 2003). The oxygen reactivity determination tests (to obtain $\mathrm{K}_{\mathrm{r}}$ only) are now more commonly conducted in cells composed of a single reservoir only (Figure 4(b)). In all these tests, the oxygen concentration measurements must last long enough to obtain a significant variation in the concentration in the instrumented reservoir (i.e. a change of at least 3-5\%). More information on the testing procedures and interpretation can be found in Mbonimpa and Aubertin (2003), Dagenais (2005), and Gosselin et al. (2007).

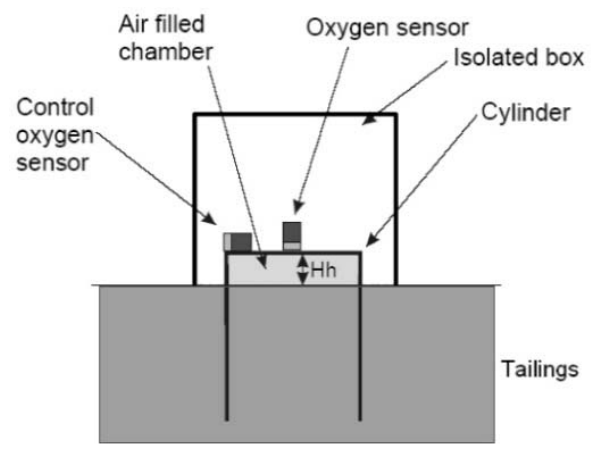

(a)

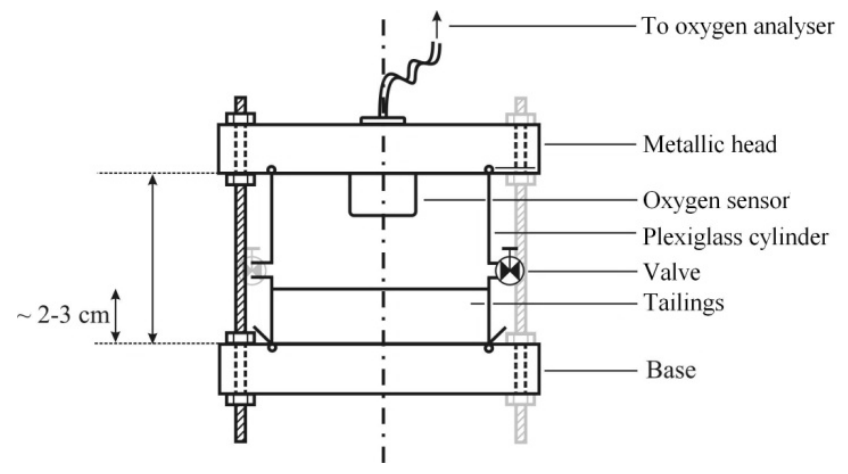

(b)

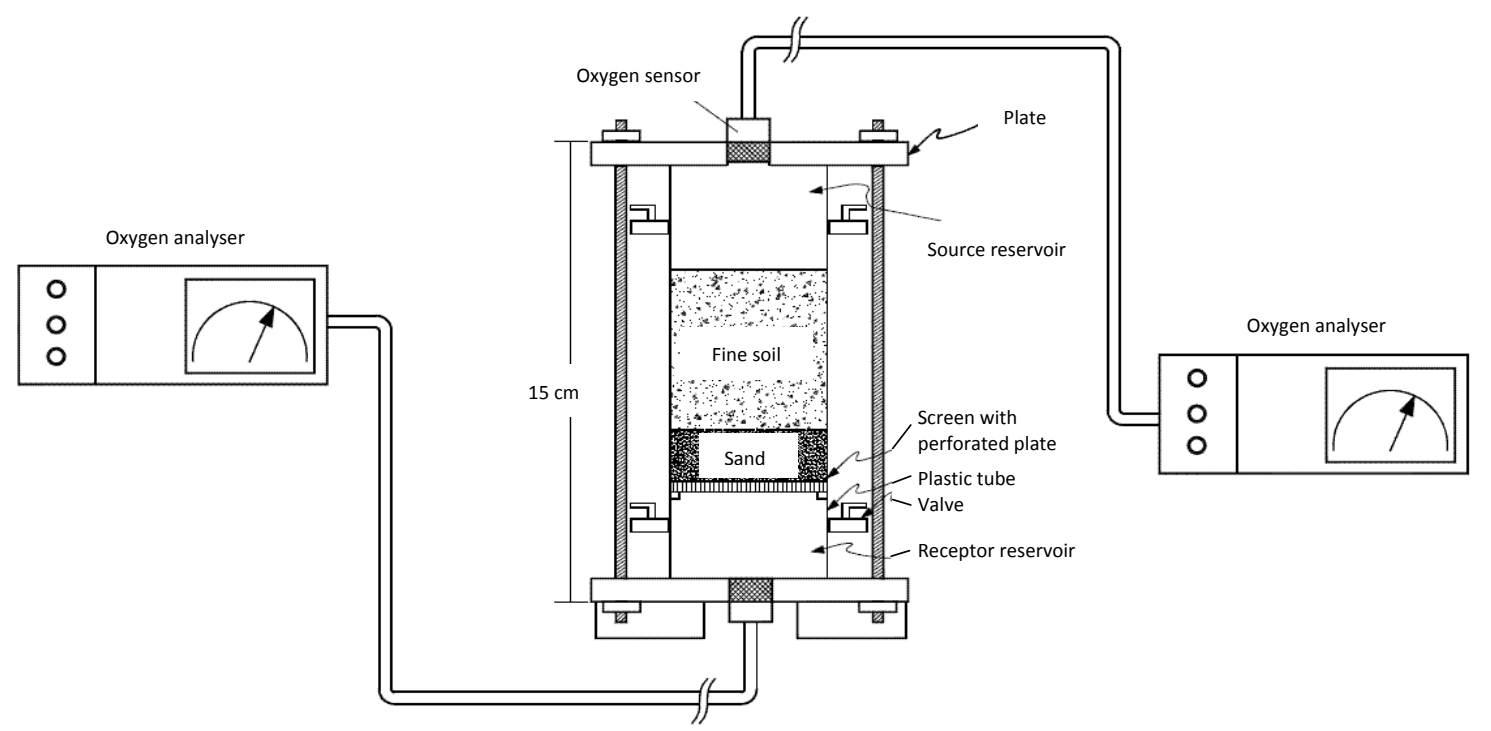

(c)

Figure 4 Schematic representations of the testing set up developed to evaluate the oxygen diffusion and consumption rate coefficients in tailings; a) in the field (Martin et al., 2006b); b) in the laboratory with a consumption cell (adapted from Gosselin, 2007); c) with the tworeservoir diffusion-consumption cell (Mbonimpa and Aubertin, 2003)

The main underlying assumption at the core of these tests is that molecular diffusion is the controlling oxygen transport mechanism. The one-dimensional diffusive flux of oxygen $\mathrm{F}(\mathrm{z}, \mathrm{t})$ in an unsaturated porous medium can then be defined using Fick's first law (Aubertin et al., 2000):

$$
\mathrm{F}(\mathrm{z}, \mathrm{t})=-\mathrm{D}_{\mathrm{e}} \frac{\partial \mathrm{C}(\mathrm{z}, \mathrm{t})}{\partial \mathrm{z}}=-\theta_{\mathrm{eq}} \mathrm{D}^{*} \frac{\partial \mathrm{C}(\mathrm{z}, \mathrm{t})}{\partial \mathrm{z}}
$$


where $C(z, t)$ is the concentration of oxygen at time $t$ and depth from surface $z\left[M L^{3}\right] ; D_{e}$ the effective diffusion coefficient $\left[\mathrm{L}^{2} \mathrm{~T}^{-1}\right]$; $\theta_{\mathrm{eq}}$ the equivalent (diffusion) air porosity [dimensionless]; and $\mathrm{D}^{*}$ the bulk diffusion coefficient $\left[\mathrm{L}^{2} \mathrm{~T}^{-1}\right]$ expressed as: $\mathrm{D}^{*}=\mathrm{D}_{\mathrm{e}} / \theta_{\mathrm{eq}}$.

In Equation (1), the equivalent air porosity $\theta_{\text {eq }}$ is used to take into account the flux of oxygen in the air phase and in the water phase (Aubertin et al., 2000); it is defined as:

$$
\theta_{\text {eq }}=\theta_{\mathrm{a}}+\mathrm{H} \theta_{\mathrm{w}}
$$

where $\theta_{\mathrm{w}}($ or $\theta)$ is the volumetric water content [dimensionless]; $\theta_{\mathrm{a}}$ is the volumetric air content [dimensionless] defined as: $\theta_{\mathrm{a}}=\mathrm{n}-\theta_{\mathrm{w}}$, where $\mathrm{n}$ is the soil total porosity [dimensionless]; and $\mathrm{H}$ is Henry's equilibrium constant $\left(\mathrm{H} \approx 0.03\right.$ at $20^{\circ} \mathrm{C}$ for oxygen).

The flow of oxygen may be influenced by the oxidation reaction when the tailings contain sulphide minerals (like pyrite). This reaction is usually controlled by first order kinetics (Nicholson et al., 1989), which means that the oxygen reaction rate is linearly related to its concentration. The oxygen consumption can then be introduced into Fick's second law as follows (Mbonimpa and Aubertin, 2003):

$$
\frac{\partial \mathrm{C}}{\partial \mathrm{t}}=\mathrm{D}^{*} \frac{\partial^{2} \mathrm{C}}{\partial \mathrm{z}^{2}}-\mathrm{K}^{*} \mathrm{C}
$$

$\mathrm{K}^{*}$ is the bulk oxygen reactivity rate coefficient, which is related to the oxygen reactivity rate coefficient $\mathrm{K}_{\mathrm{r}}$ $\left[\mathrm{K}^{*}=\mathrm{K}_{\mathrm{r}} / \theta_{\text {eq }}, \mathrm{L}^{3} \mathrm{~L}^{-3} \mathrm{~T}^{-1}\right.$ or $\left.\mathrm{T}^{-1}\right]$. Equation (3) assumes that the water content does not change over time and space, for the calculation period. This equation is used for the interpretation of the MOC test (Mbonimpa and Aubertin, 2003). Because it must be solved concurrently for both the diffusion and reaction rate coefficients, it is usually necessary to use a numerical method since no analytical solution exists under transient conditions. The authors have used the software POLLUTE (Rowe et al., 1998) to interpret these tests. The MOC test interpretation is based on a comparison between the measured and the simulated evolution of the oxygen concentration in the reservoir(s). An iterative process is used, where values of $\mathrm{D}^{*}$ and $\mathrm{K}^{*}$ are adjusted to match the measured results. The selected value of the oxygen bulk diffusion $\mathrm{D}^{*}$ and reaction rate $\mathrm{K}^{*}$ coefficients are those that give a 'best fit' to the experimental data. These two parameters are associated with the effective diffusion coefficient $D_{e}$ and the reaction rate coefficient $K_{r}$ (using the equivalent porosity $\theta_{\text {eq }}$ ). The experimentally determined values can be used subsequently to calculate the flux of oxygen into the exposed tailings. More information on these tests and their interpretation can be found in Mbonimpa and Aubertin (2003), and Gosselin (2007).

Oxygen diffusion occurs more rapidly when the degree of saturation of the medium is low (e.g. Aachib et al., 2004). The diffusion flux becomes very small when $S_{r}$ is above about $85 \%$, i.e. when the effective diffusion coefficient is approximately equal to the diffusion coefficient in water (Aubertin et al., 2000, 2002). The value of $D_{e}$ is mainly dependent on the basic properties of the material (such as its PSD and porosity) and on the degree of saturation, which influence the tortuosity and continuity of the oxygen flow path in the porous medium.

The results from field and laboratory tests indicate that the tailings from Bulyanhulu mine are reactive, which is to be expected since these tailings contain approximately $12 \%$ pyrite (Martin et al., 2005). The reaction rate coefficients $\left(\mathrm{K}_{\mathrm{r}}\right)$ deduced from field measurements are between $2.65 \mathrm{~d}^{-1}$ and $54.76 \mathrm{~d}^{-1}$, for degrees of saturation $\left(\mathrm{S}_{\mathrm{r}}\right)$ of $92 \%$ and $60 \%$, respectively (Martin et al., 2006b). Gosselin (2007) measured the coefficient in the laboratory, and obtained $\mathrm{K}_{\mathrm{r}}$ values that varied between $0.91 \mathrm{~d}^{-1}$ and $12.75 \mathrm{~d}^{-1}$.

\subsection{Column tests}

In parallel with the characterisation of the Bulyanhulu tailings, some columns were setup as physical models to evaluate specific characteristics linked to surface paste tailings disposal. The objective of the laboratory columns tests (Figures 5(a) and 5(b)) is to investigate the response of tailings based on the behaviour of a meso-scale model that mimic certain aspects of TSF. The columns are about $30 \mathrm{~cm}$ in diameter and approximately $45 \mathrm{~cm}$ tall. They are used to create different deposition scenarios by varying parameters such 
as exposure time, wetting-drying cycles, and layer thickness; and to evaluate the impact of such variables on the hydrogeotechnical response of the materials. More specifically, the test consists of depositing layers (of predetermined thicknesses) of paste tailings (Buly-04 or Buly-07 tailings) in the columns, which are then left to "age" as they are exposed to the natural conditions in the laboratory. The gravimetric pulp density during deposition is typically between $70 \%$ and $75 \%$, which is similar to that observed at the Bulyanhulu mine. At predetermined time intervals (between two and four weeks), additional layers are added on top of the older tailings; enough time is allowed for the layers to desaturate through consolidation, drainage and evaporation. The distribution of pore water in the tailings (and its variation through time) is monitored by measuring pressures and volumetric water contents.

The columns are instrumented with sensors that measure the following parameters:

- Pore water pressure, with:

- PX240 tensiometers by Omega ( $\pm 100 \mathrm{kPa})$ fitted with a ceramic cup (100 kPa air entry value), one per tailing layer

- watermark sensors by Irrometer Company, Inc. (suction down to $-200 \mathrm{kPa}$ ), one per tailing layer

- T-5 Tensiometer by UMS (suction down to $-85 \mathrm{kPa}$ - this is a low disturbance tensiometer installed to measure variations of suction close to the surface), one at the surface.

- Volumetric water content (one sensor per tailing layer), with:

- coated TDR probes by Soilmoisture Equipment Corp. (for first two tests, oxidation of the probes limited their use afterwards)

$\circ \mathrm{EcH}_{2} \mathrm{O}-\mathrm{EC}-5$ Soil moisture sensors by Decagon Devices (for the third test and on).

- Surface displacement, with:

- LVDT probes by Trans-Tek Inc. (two sensors), installed on the surface of the tailing to measure the settlement and consolidation following deposition.

- Oxygen consumption and diffusion, with:

- SO-111 oxygen sensor by Apogee Instruments Inc., placed on top of a sealed reservoir in the column (as seen on Figure 5(a)); the tests are completed at regular time intervals (every 4 to 6 days) to evaluate the change in the oxygen consumption and diffusion as the tailing desaturates (as explained in Section 2.1.4). This sensor is removed between tests.

As seen on Figure 5, the column, which is installed on an electronic scale, includes a water outlet (free drainage) at the bottom. This allows a measure of the mass changes through the cycle, due to actual evaporation and drainage of water. The potential evaporation (as defined in Wilson et al., 1997) is measured by weighing, on a daily basis, a similarly shaped column filled with water (free surface).

The column is instrumented and connected to a data acquisition system on a computer, to follow, almost in real time, the evolution of the tailings characteristics. Figure 5(a) shows a column with four $10 \mathrm{~cm}$ layers of tailings. Some tests have also been completed with two $20 \mathrm{~cm}$ layers, so the impact of layer thickness on the evolution of the tailings properties could be assessed. The temperature and relative humidity in the laboratory are also monitored (average values of $25^{\circ} \mathrm{C}$ and $60 \%$, respectively, with little variability during the year). 


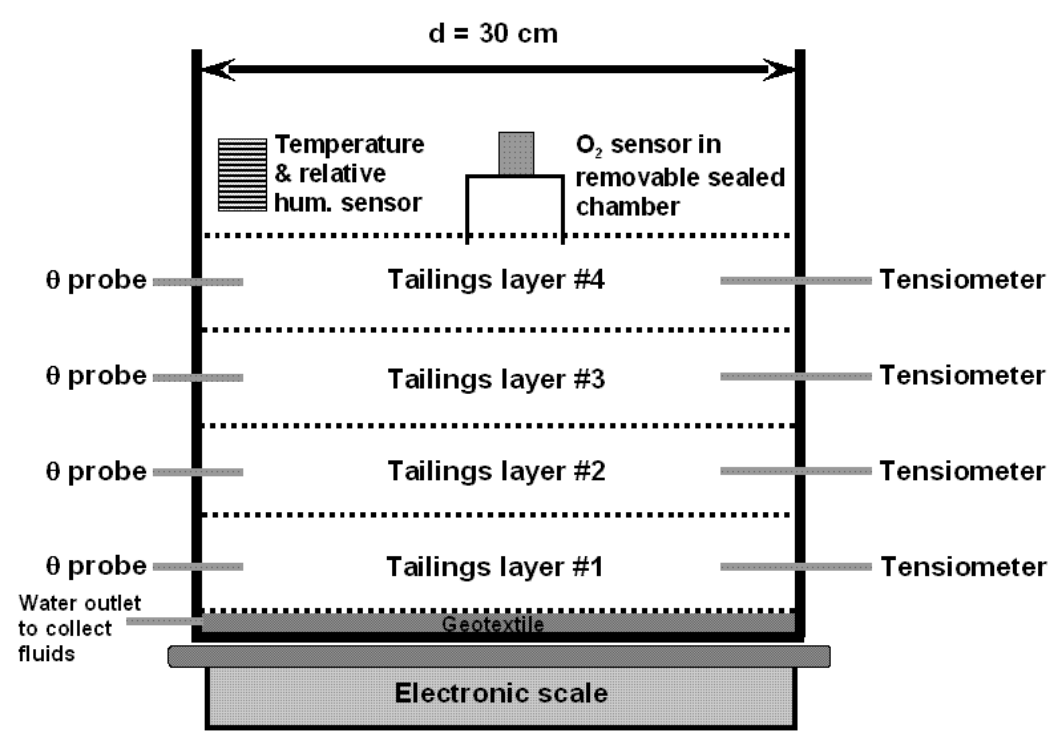

(a)

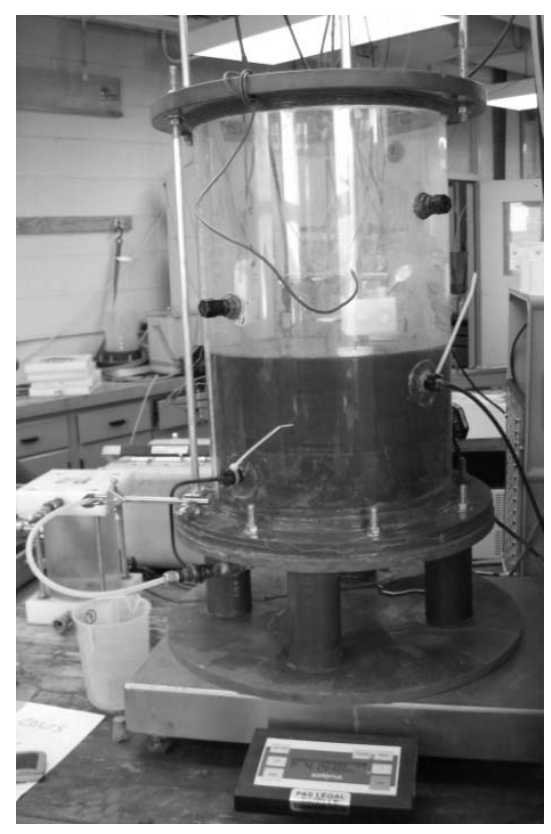

(b)

Figure 5 Schematic representation (a) and photograph (b) of the laboratory columns designed to study surface paste tailings disposal

Much of monitoring of the column tests is based on following the evolution of the water contents and pore water pressures in the tailings. The direction of the flow of water is also of interest (i.e. downwards by drainage or upwards by evaporation). Four columns tests completed to date, with the Bulyanhulu tailings, indicate that, after an initial drainage period of 4 to 6 days, the ongoing weight loss is almost exclusively due to evaporation of the pore water. When an additional layer was deposited (between two and four weeks later) on top of a drying layer, there was no flow registered at the base; part of the water was transferred to the dryer material below, and the remaining water loss occurred through evaporation. This lack of downward drainage trough the port hole can be linked, in part, to the ability of the Bulyanhulu fine-grained tailings to retain water by capillarity (as seen in Section 2.1.3). It could be inferred from these experimental results that the lower water content (compared with traditional slurried tailings) of paste tailings tend to produce less downward drainage of water, at least when there is not water addition (by infiltration) on top. Additional results with cyclically wetted columns will be presented in Martin (2010).

Oxygen consumption and diffusion tests were also completed at regular intervals at the surface of the tailings in the columns. These tests measured the evolution of the oxygen concentration in a sealed reservoir in order to evaluate the variations in the diffusion and reaction rate coefficients of the tailings (Mbonimpa and Aubertin, 2003; Dagenais, 2005; Martin et al., 2006b). Figure 6 presents the results for three oxygen consumption/diffusion tests completed at different tailings water contents (or different suctions); these results are presented with respect to suction $(\psi)$ and not volumetric water content $(\theta)$ as the TDR probes used to measure $\theta$ did not work appropriately in these tailings. In this case, lower suctions can be related to higher water contents (or degrees of saturation), as shown by the WRCs in Figure 3. It can be seen on Figure 6 that the oxygen concentration decreases more rapidly when the suction is higher, i.e. for a lower water content. 


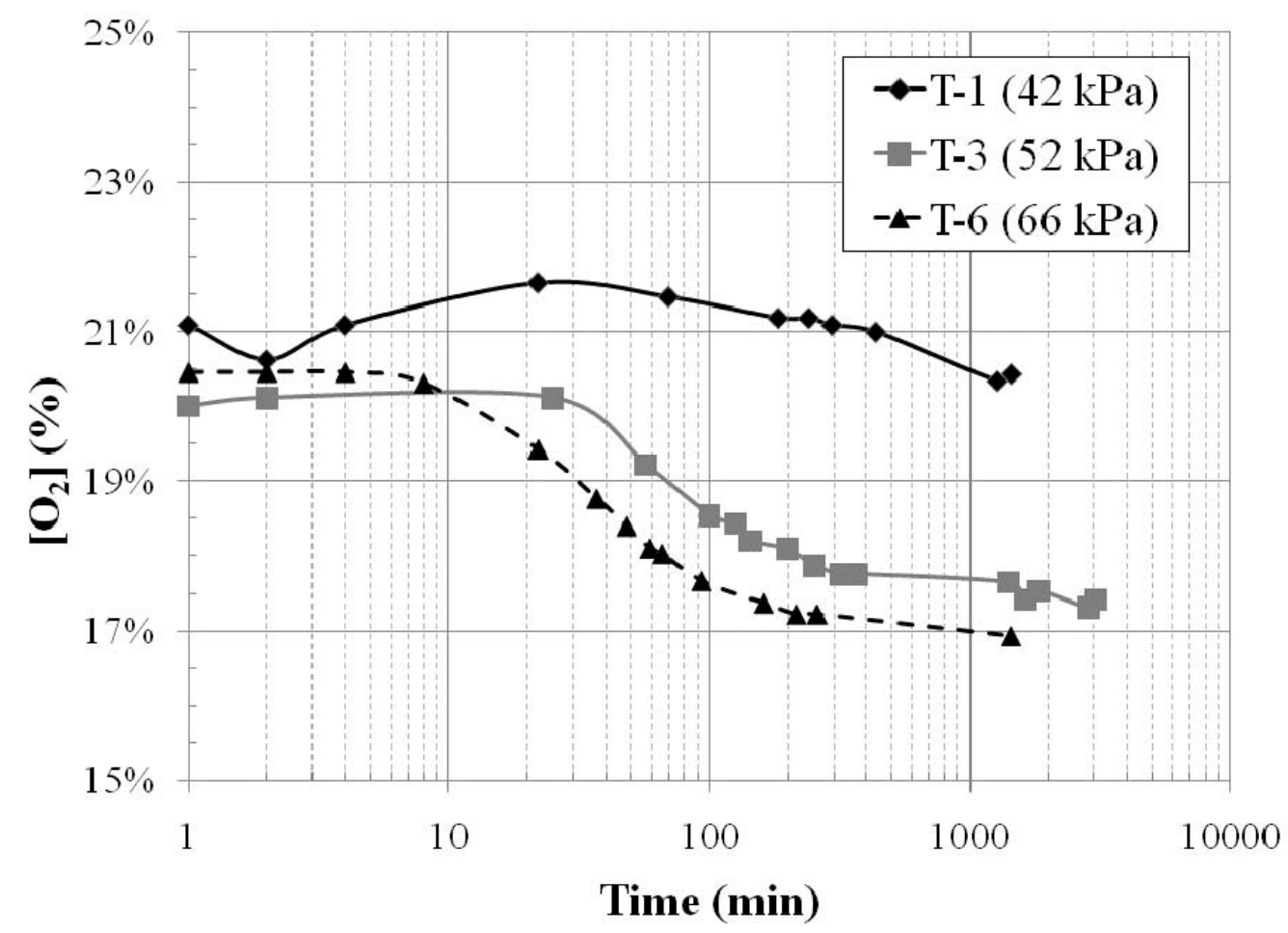

Figure 6 Evolution of the oxygen concentration in a closed reservoir at the surface of column test Buly-02d (with Buly-04 tailings) for three suction values (corresponding to 3 water contents)

As paste tailings contain less pore water than traditional tailings, their rate of desaturation (following deposition) may become critical. This aspect of paste tailings behaviour can be of concern when these are potentially acid generating. More specifically, desaturation by evaporation could lead to increased oxidisation and acid mine drainage. Thus, the tailings deposition cycle must be planned accordingly to minimise such desaturation of each tailings layer, to limit their oxidation.

\section{$3 \quad$ Numerical modelling}

A 1-d numerical model of the Bulyanhulu TSF was constructed using the finite element modelling software Vadose/W (GeoSlope International). This software allows the use of daily climatic conditions at the surface of the model to reproduce field conditions. The conditions applied at the top of this model were based (in some cases) on climatic data measured on the mine site during seven years (from 1999 to 2006). The model presented here consists of 12 meters of paste tailings (final planned elevation of the facility at Bulyanhulu mine) on top of 12 meters of native soil (corresponding to the depth to the water table; WEGS, 2002). The material properties (water retention curve and saturated hydraulic conductivity) of the Bulyanhulu tailings used in the model are the ones measured in the laboratory, whereas the properties of the underlying soil were obtained from reports issued by consulting firms (Golder Associates Ltd, 1997; Kilborn, 1998), and extrapolated using the modified Kovàcs (MK) model (Aubertin et al., 2003) to obtain the water retention curve of the soil. The degree of saturation of in the tailings was $100 \%$ at the beginning of the modelling sequence. The model was run for seven years. The average yearly climatic conditions at the Bulyanhulu mine consist of $850 \mathrm{~mm}$ of precipitation and $1,510 \mathrm{~mm}$ of potential evaporation (Zhan, 2010, written comm.). This is considered a tropical savannah climate (Aw) according to the Koppen classification system (monthly precipitation data from SRK, 2002). The rainy season ( $70 \%$ of the total precipitation) extends from November to April (Kilborn, 1998; SRK, 2002). The actual evaporation (AE) was calculated using Vadose/W with user defined climatic conditions.

One of the objectives of these calculations was to estimate the position of the zero flux plane (ZFP). The ZFP can be defined as the depth in the soil (or tailings) where the total potential hydraulic gradient $\left(\mathrm{dH} / \mathrm{dz}\right.$, or $\left.\mathrm{i}_{\mathrm{y}}\right)$ 
is nil (Miyazaki, 2006). It corresponds to the plane that delimits upward and downward water movements. In other words, water above the ZFP will tend to move upward and may eventually evaporate, whereas water below the plane will flow downward to the base of the system, i.e. the water table, in this case.

Figure 7 presents the vertical hydraulic gradients with respect to time obtain from the numerical model. It must be noted that a positive gradient means upward flow and a negative gradient, downward flow. The values of the gradient are shown at the beginning of March for each of the years modelled. This corresponds roughly to the peak of the rainy season at the Bulyanhulu mine. It can be observed on Figure 7 that, once the model attains a pseudo-equilibrium, the position of the ZFP starts levelling and stays approximately $1.5 \mathrm{~m}$ below the soil surface (Figure 8). A second model (not shown), was run for an extra seven years (with the same climatic boundary) and the results confirmed this trend. The positive gradient in the tailings indicates the importance of evaporation on the water balance for the Bulyanhulu TSF. It must be stated that the model does not take into account the sequential deposition of saturated tailings layers that could, potentially, increase the downwards desaturation, i.e. drainage. Moreover, in the first years of the model, some drainage has been observed from the tailings, so it cannot be stated that all desaturation is caused exclusively by evaporation. However, this model demonstrates the overall importance of evaporation on the water balance of a tailings storage facility filled with paste tailings.

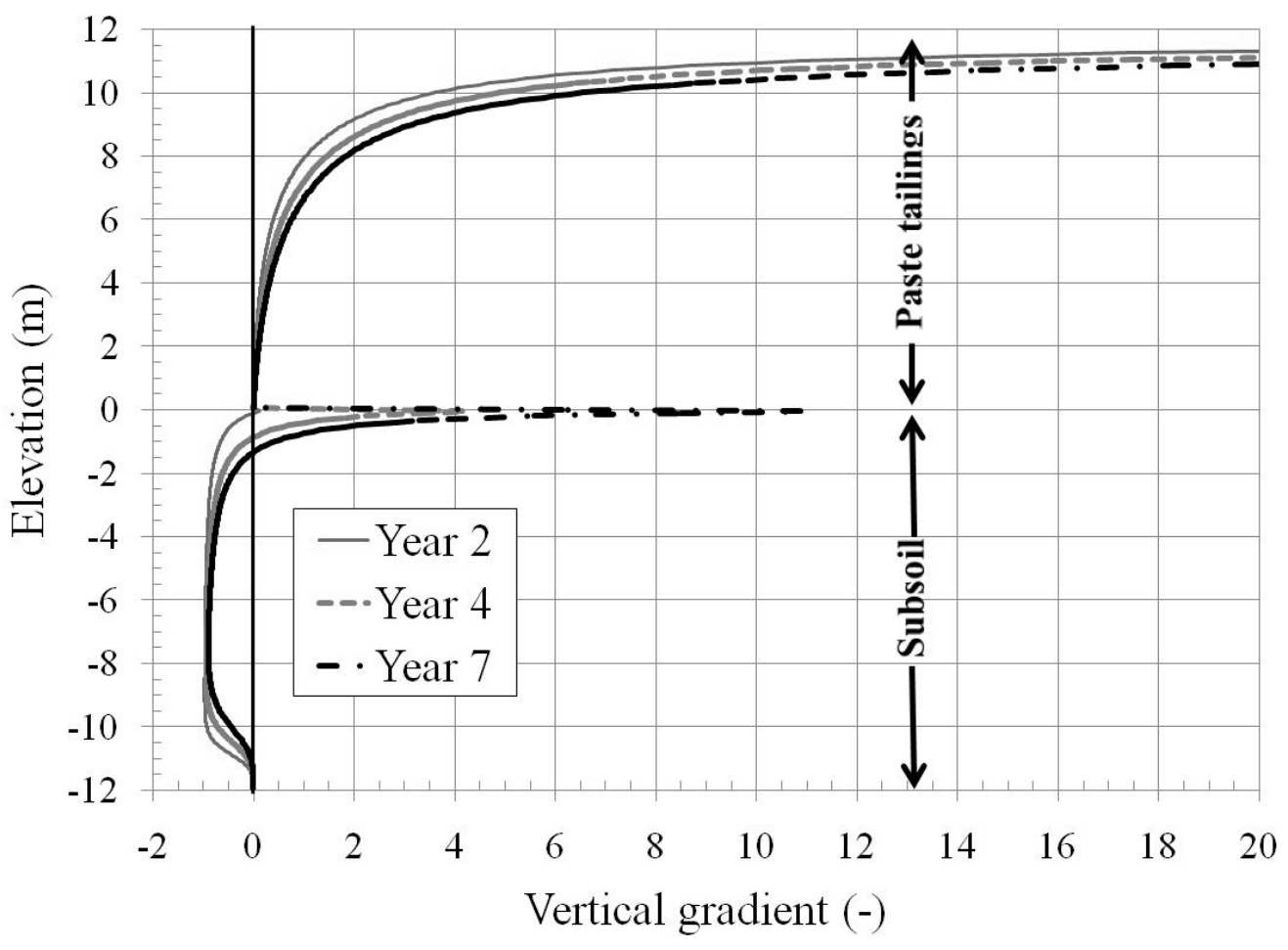

Figure 7 Vertical hydraulic gradient with respect to depth obtained from the one-dimensional numerical simulation of the Bulyanhulu tailings storage facility 


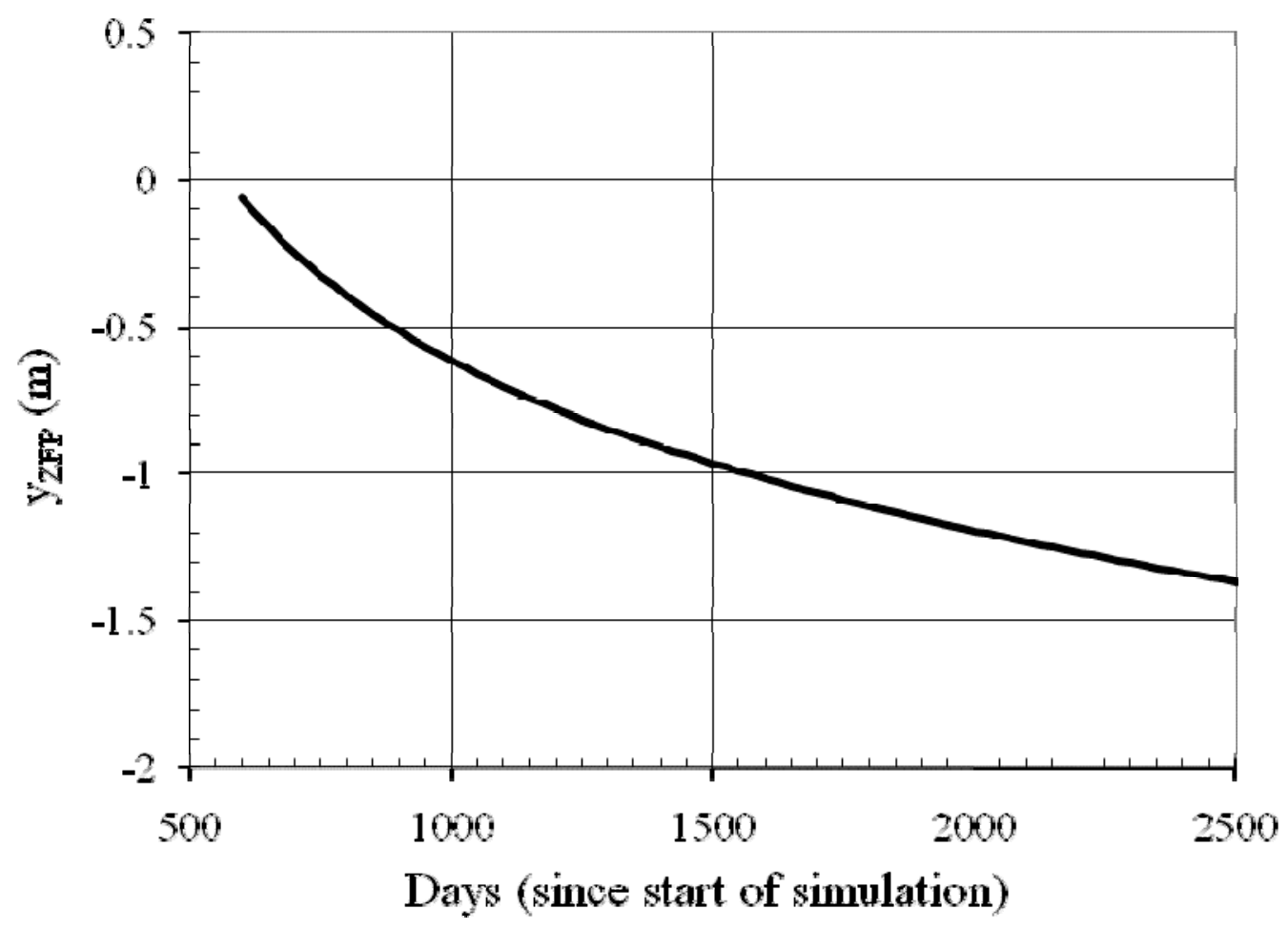

Figure 8 Depth of the zero flux plane ( $\left.\mathrm{y}_{\mathrm{ZFP}}\right)$ from the ground surface $(\mathrm{y}=\mathbf{0} \mathrm{m}$; tailings surface is at $y=12 \mathrm{~m}$ ) with respect to time in the 1-d Bulyanhulu tailings model completed with Vadose/W

\section{$4 \quad$ Discussion and closing remarks}

As presented above, the laboratory results tend to show that, following the onset of tailings desaturation (which occurs at a suction of roughly $50 \%$ of the air entry value for those studied in this case), the main mechanism driving water flow appears to be evaporation. This leads to believe that evaporation thus plays an important role in the water balance of a tailings facility constructed with paste tailings. The relatively low water content for these tailings, regardless of the advantages, allow desaturation to occur more rapidly than in slurried tailings. When sulphide minerals are present, this may be a concern if the tailings are potentially acid generating. The preliminary results from the laboratory column tests and numerical simulations tend to confirm this trend; as the rate of oxygen depletion increases as the tailings desaturate (which may increase AMD production if the mine tailings are potentially acid generating).

The presence of a positive vertical gradient to a depth of approximately $13 \mathrm{~m}$ (from the tailings surface) in the numerical simulation presented above tend to confirm that desaturation by evaporation is quite important. It must be recalled that the numerical simulations have been conducted using the climatic conditions of the Bulyanhulu mine in Tanzania (measured from 1999 to 2006). At this site, the climate is that of a tropical savannah and consists of a six month dry season, followed by six months of precipitation (high intensity/short duration daily rainfalls). It would be interesting to conduct similar calculations for different climatic conditions such as the climate of mining areas like northern Ontario and Quebec.

Further work in this project includes the study of wetting and drying cycles on the properties of the paste tailings in columns, especially with respect to the oxygen diffusion and consumption and to the potential drainage of the material. Moreover, a parametric study will be completed using the Bulyanhulu numerical model in order to evaluate the impact of certain parameters (e.g. particle size distribution, water retention curve, hydraulic conductivity, climatic conditions, position of the water table, etc.) on the position of the zero flux plane and on the related surface exchanges. Moreover, a numerical model taking into account the sequential deposition of paste tailings (as it occurs in the field) could bring new light to the flow of water in these materials. In addition, a model studying the interaction between the oxygen and pore water fluxes (which has an impact on the oxidation of reactive tailings) would also be beneficial. 
Surface disposal of paste tailings may, in certain circumstances, be a viable and durable solution for tailings management. It is, however, important to take into account the specific properties of the site (climate, underlying soils, production rate, etc.) and of the tailings (particle size distribution, hydraulic conductivity, reactivity, etc.) when designing and operating a tailings storage facility with these materials.

\section{Acknowledgements}

The authors would like to thank the personnel from the Bulyanhulu Mine for the technical and logistical support, for the information on surface paste tailings, and for the tailings samples. We would also like to extend our gratitude to Barrick Gold Corporation, and especially Jacques McMullen for their support of this work. This project is completed as part of the program of the Industrial NSERC Polytechnique-UQAT Chair in Environment and Mine Wastes Management (http://www.polymtl.ca/enviro-geremi/).

\section{References}

Aachib, M., Mbonimpa, M. and Aubertin, M. (2004) Measurement and prediction of the oxygen diffusion coefficient in unsaturated media, with applications to sil covers, Water, Air and Soil Pollution, Vol. 156, pp. 163-193.

Aubertin, M., Bussière, B. and Chapuis, R.P. (1996) Hydraulic Conductivity of Homogenized Tailings from Hard Rock Mines, Canadian Geotechnical Journal, Vol. 33, pp. 470-482.

Aubertin, M., Aachib, M. and Authier, K. (2000) Evaluation of Diffusive Gas Flux through Covers with a GCL, Geotextile and Geomembranes, Vol. 18, pp. 1-19.

Aubertin, M., Bussière, B. and Bernier, L. (2002) Environnement et gestion des rejets miniers, Les Presses Internationales de Polytechnique.

Aubertin, M., Mbonimpa, M., Bussière, B. and Chapuis, R.P. (2003) A Model to Predict the Water Retention Curve from Basic Geotechnical Properties, Canadian Geotechnical Journal, Vol. 40, pp. 1104-1122.

Benzaazoua, M., Perez, P., Belem, T. and Fall, M. (2004) A Laboratory Study of the Behaviour of Surface Paste Disposal, Minefill 2004 - The 8th International Symposium of Mining with Backfill, The Nonferrous Metals Society of China, pp. 180-192.

Blight, G.E. (2003) Quantified Comparisons of Disposal of Thickened and Unthickened Tailings, Tailings and Mine Waste '03, A.A. Balkema Publishers, pp. 63-71.

Bussière, B., Dagenais, A-M., Mbonimpa, M. and Aubertin, M. (2002) Modification of Oxygen-Consumption Testing for the Evaluation of Oxygen Barrier Performance, Canadian Geotechnical Society, pp. 139-146.

Bussière, B. (2007) Colloquium 2004: Hydro-Geotechnical Properties of Hard Rock Tailings from Metal Mines and Emerging Geo-Environmental Disposal Approaches, Canadian Geotechnical Journal, Vol. 44, pp. $1019-1052$.

Crowder, J.J. (2004) Deposition, consolidation, and strength of a non-plastic tailings paste for surface disposal, Ph.D. Thesis in Civil Engineering, University of Toronto, $162 \mathrm{p}$.

Dagenais, A-M. (2005) Techniques de contrôle du drainage minier acide basées sur les effets capillaires, Ph.D. Thesis in Mineral Engineering, École Polytechnique de Montréal, 394 p.

Deschamps, T. (2009) Study of the physical and hydrogeochemical behaviour of surface paste disposal, Ph.D. Thesis in Environmental Sciences, Université du Québec, 315 p.

Elberling, B., Nicholson, R.V., Reardon, E.J. and Tibble, P. (1994) Evaluation of Sulphide Oxidation Rates: A Laboratory Study Comparing Oxygen Fluxes and Rates of Oxidation Product Release, Canadian Geotechnical Journal, Vol. 31, pp. 375-383.

Fredlund, D.G. and Rahardjo, H. (1993) Soil mechanics for unsaturated soils, John Wiley \& Sons, Inc., 517 p.

Golder Associates Ltd (1997) Geotechnical Assessment, Tailings Management Facility, Bulyanhulu Mining Project, Kahama District, Tanzania, 27 p., (plus appendices).

Gosselin, M. (2007) Étude de l'influence des caractéristiques hydrogéochimiques des résidus miniers réactifs sur la diffusion et la consommation de l'oxygène, M.Sc.A. Thesis in Mineral Engineering, École Polytechnique de Montréal, $215 \mathrm{p}$.

Gosselin, M., Aubertin, M. and Mbonimpa, M. (2007) Évaluation de l'effet du degré de saturation sur la diffusion et la consommation d'oxygène dans des résidus miniers sulfureux, Canadian Geotechnical Society, pp. 1431-1438.

Jewell, R.J., Fourie, A.B. and Lord, E.R. (2002) In Paste and Thickened Tailings - A Guide, R.J. Jewell, A.B. Fourie and E.R. Lord (eds), Australian Centre for Geomechanics, Perth, Australia, 173 p.

Kilborn-SNC Lavallin (Kilborn) (1998) Bulyanhulu Feasibility Study, Volume I - Sections 2, 8, 9.

Kleinmann, R.L.P., Crerar, D.A. and Pacelli, R.R. (1981) Biogeochemistry of Acid Mine Drainage and a Method to Control Acid Formation, Mining Engineering, Vol. 33, pp. 300-305.

Li, M., Bernier, L. and Boucher, J-F. (2002) Rheology of Mineral Pastes and its Implications on Underground Pipeline Delivery, Symposium 2002 on Environment and Mines, Canadian Institute of Mining, Metallurgy and Petroleum. 
Martin, V., McMullen, J. and Aubertin, M. (2005) Les résidus en pâte et la déposition en surface des rejets de concentrateur, Symposium 2005 on mines and the environment, Canadian Institute of Mining, Metallurgy and Petroleum.

Martin, V., Aubertin, M. and McMullen, J. (2006a) Surface Disposal of Paste Tailings, 5th International Congress on Environmental Geotechnics, International Society for Soil Mechanics and Geotechnical Engineering, pp. 26-30.

Martin, V., Aubertin, M., Bussière, B., Mbonimpa, M., Dagenais, A-M. and Gosselin, M. (2006b) Measurement of Oxygen Consumption and Diffusion in Exposed and Covered Reactive Mine Tailings, 7th International Conference on Acid Rock Drainage, Society for Mining, Metallurgy and Exploration.

Martin, V. (2010) Evolution of the hydrogeotechnical properties of paste tailings deposited on surface, Ph.D. Thesis in Mineral Engineering, École Polytechnique de Montréal, unpublished.

Mbonimpa, M. and Aubertin, M. (2003) Mouvement des gaz en milieux poreux partiellement saturés, Éditions de l'École Polytechnique, $45 \mathrm{p}$.

Mbonimpa, M., Aubertin, M., Chapuis, R.P. and Bussière, B. (2002) Practical Pedotransfer Functions for Estimating the Saturated Hydraulic Conductivity, Geotechnical and Geological Engineering, Vol. 20, pp. 235-259.

Miyazaki, T. (2006) Water flow in soils, 2nd edition, Taylor and Francis, 418 p.

Nicholson, R.V., Gillham, R.W., Cherry, J.A. and Reardon, E.J. (1989) Reduction of Acid Generation in Mine Tailings Through the Use of Moisture-Retaining Cover Layers as Oxygen Barriers, Canadian Geotechnical Journal, Vol. 26, pp. 1-8.

Ouangrawa, M., Molson, J., Aubertin, M., Bussière, B. and Zagury, G.J. (2006) The Effect of Water Table Elevation on Acid Mine Drainage from Reactive Tailings: A Laboratory and Numerical Modelling Study, 7th International Conference on Acid Rock Drainage, Society for Mining, Metallurgy and Exploration, pp. 1473-1482.

Ouangrawa, M., Molson, J., Aubertin, M., Bussière, B. and Zagury, G.J. (2009) Reactive Transport Modelling of Mine Tailings Columns with Capillarity-Induced High Water Saturation for Preventing Sulphide Oxidation, Applied Geochemistry, Vol. 24, pp. 1312-1323.

Robinsky, E.I. (1999) Thickened tailings disposal in the mining industry, Robinsky Associates Ltd., 210 p.

Rowe, R.K., Booker, J.R. and Fraser, M.J. (1998) POLLUTE v6 and POLLUTE-GUI User's Guide, GAEA Environmental Engineering Ltd., 305 p.

Saleh-Mbemba, F., Aubertin, M. and Li, L. (2010) A New Testing Procedure to Assess Shrinkage of Paste Tailings, Paste 2010, Australian Centre for Geomechanics, Perth, Australia (in press).

Sofra, F. and Boger, D.V. (2002) Environmental Rheology for Waste Minimisation in the Minerals Industry, Chemical Engineering Journal, Vol. 86, pp. 319-330.

Steffen, Robertson and Kirsten (South Africa) (Pty) Ltd (SRK) (2002) Kahama Mining Corporation Limited, Tanzania, Reclamation and Closure Plan for the Bulyanhulu Mine, 66 p. (plus appendices).

Van Genuchten, M.T. (1980) A Closed-Form Equation for Predicting the Hydraulic Conductivity of Unsaturated Soils, Soil Science Society of America Journal, Vol. 44, pp. 892-898.

Vick, S.G. (1983) Planning, Design, and Analysis of Tailings Dams, John Wiley \& Sons, 369 p.

WEGS Consultants (WEGS) (2002) Hydrogeological Review and Assessment of Groundwater Monitoring and Contamination Risk at Bulyanhulu Gold Mine, 19 p. (plus appendices).

Wilson, G.W., Fredlund, D.G. and Barbour, S.L. (1997) The Effect of Soil Suction on Evaporative Fluxes from Soil Surfaces, Canadian Geotechnical Journal, Vol. 34, pp. 145-155. 